\title{
Cell-Free Translation of Messenger RNAs from Human Muscle Biopsies: a Miniaturized Tool for Investigation of Neuromuscular Diseases
}

\author{
ARNOLD MUNNICH, DOMINIQUE DAEGELEN, CLAUDE BESMOND, JOËLLE MARIE, JEAN- \\ CLAUDE DREYFUS, AND AXEL KAHN ${ }^{(14)}$ \\ Institut de Pathologie Moléculaire, CHU Cochin, 75674 PARIS Cedex 14 France
}

\begin{abstract}
Summary
Starting from children and adult skeletal muscle biopsy specimens $(150 \mathrm{mg})$, we devised a scaled-down technique for isolation and cell-free translation of total cellular messenger RNAs in a reticulocyte-lysate system. Moreover, starting from $200 \mathrm{mg}$ of human muscle, the technique allowed us to purify a neosynthesized protein, glycogen phosphorylase b (EC 2.4.1.1), using a specific immunoafínity microchromatography procedure.

\section{Speculation}

These results show that several neuromuscular diseases can now be investigated with the new tools of molecular biology, especially when the specific immunoabsorbent is available. If one considers the innocuity of a needle ( $80 \mathrm{mg}$ of tissue per puncture) or surgical biopsy taking such small amounts of muscle, it is tempting to imagine the potential applications of these techniques for studying the mechanism of several inherited childhood metabolic diseases and for investigating pathologic changes in gene expression.
\end{abstract}

The recent advances in molecular biology have provided new tools for the study of genetic disorders in man and for the understanding of pathologic changes in gene expression. However, an adaptation of these techniques to small amounts of human tissue is required before using them as a tool of investigation in the study of genetic diseases.

We have developed a scaled down method for purification of total ribonucleic acids (RNAs) from biopsy specimens of human skeletal muscle. This method yields highly translatable messenger RNA, which directs the synthesis of high molecular weight protein chains in a cell-free system. The high efficiency of this technique allows the purification of neosynthesized proteins from the cellfree translation product. This can be achieved using immunoaffinity microchromatographic procedures, as we show with anti-muscle glycogen phosphorylase b antibodies (E.C.2.4.1.1).

The study of muscular proteins produced by patients' RNAs in cell-free systems could be of great interest for understanding several neuromuscular diseases.

\section{MATERIALS AND METHODS}

Materials. Most reagents were bought from sources identified in previous papers (9).

No-Screen and Royal X-Omatic R-I films were supplied by Eastman Kodak (Rochester, NY, USA); $\left[{ }^{35} \mathrm{~S}\right]$-methionine and $\left[{ }^{3} \mathrm{H}\right]$ -leucine, Econofluor, Protosol, and $\mathrm{En}^{3} \mathrm{Hance}$ autoradiography Enhancer by New England Nuclear (Boston, MA, USA). Radioactivity was measured in a liquid scintillation counter LKB (1215 Rackbeta model). Dodecyl sulphate/polyacrylamide slab gels were prepared in the laboratory, using a Uniscil gradient former
(Universal Scientific Limited, London, Great Britain) and electrophoreses were performed using an apparatus furnished by the same firm.

Human skeletal muscle specimens were obtained by surgical biopsies of the deltoid and vastus lateralis on normal 14-70-yearold volunteers with their informed consent. These volunteers were undergoing operation for orthopedic purpose. Samples were immediately frozen in liquid nitrogen in aliquots of $100-1000 \mathrm{mg}$.

Isolation of RNA. Total cellular RNA from human skeletal muscle was isolated in our laboratory (Kahn et al., 9) using a method of ethanol precipitation in guanidine- $\mathrm{HCl}$ modified from Cox (3), Deeley et al. (4) and Harding et al. (8). The adaptation of this technique to small biopsy specimens required several modifications.

Frozen samples were pulverized in a prechilled mortar containing liquid nitrogen, then poured in a prechilled micro-Waring Blendor (3-20 ml) and homogenized for $2 \mathrm{~min}$ in $20 \mathrm{mM}$ sodium acetate buffer, $\mathrm{pH} 5$, containing $7 \mathrm{M}$ guanidine- $\mathrm{HCl}, 240 \mathrm{mM}$ ammonium acetate, $1 \mathrm{mM}$ dithiothreitol, $10 \mathrm{mM}$ iodoacetate, $0.5 \%$ lauroylsarcosine and $0.125 \mathrm{mg} / \mathrm{ml} E$. Coli tRNA. One hundred and fifty $\mathrm{mg}$ of tissue were mixed in $3 \mathrm{ml}$ of this solution prechilled at $-20^{\circ} \mathrm{C}$. The homogenate was centrifuged at $11,000 \mathrm{X} g$ for 30 $\min$ at $-10^{\circ} \mathrm{C}$. The supernatant fluid was filtered through a sterile gauze, then one-half volume of prechilled $\left(-20^{\circ} \mathrm{C}\right)$ ethanol was added. This solution was allowed to stand at $-20^{\circ} \mathrm{C}$ for various periods of time, ranging from $12-48 \mathrm{~h}$. The precipitate was collected by centrifugation at $11,000 \mathrm{Xg}$ for $30 \mathrm{~min}$ at $-10^{\circ} \mathrm{C}$. The precipitate was quickly dissolved at $4^{\circ} \mathrm{C}$ in a small volume of 20 $\mathrm{mM}$ sodium acetate buffer, $\mathrm{pH} 7$, containing $7 \mathrm{M}$ guanidine- $\mathrm{HCl}$, $1 \mathrm{mM}$ dithiothreitol, $10 \mathrm{mM}$ iodoacetate, $20 \mathrm{mM} \mathrm{Na}_{2}$ EDTA, $0.5 \%$ lauroylsarcosine and then acidified with 1/20 volume of $2 \mathrm{M}$ sodium acetate, $\mathrm{pH} 5$. One-half volume of ethanol was again added and, after storage at $-20^{\circ} \mathrm{C}$ for $40 \mathrm{~min}$, the precipitate was collected by centrifugation at $10,000 \mathrm{Xg}$ for $10 \mathrm{~min}$ at $-10^{\circ} \mathrm{C}$. This last step was repeated twice. The final pellet was dissolved in a minimal volume of $20 \mathrm{mM} \mathrm{Na}{ }_{2}$ EDTA, $\mathrm{pH} 7,10 \mathrm{mM}$ iodoacetate, $0.5 \%$ lauroylsarcosine, with an equal volume of $\mathrm{CHCl}_{3}$ /isoamylalcohol $(24: 1, v / v)$. The organic phase was extracted by vigorous stirring for $10 \mathrm{~min}$ at $+4^{\circ} \mathrm{C}$. The aqueous phase was separated by low-speed centrifugation. The organic phase was extracted once more with one-half volume of $20 \mathrm{mM} \mathrm{Na}{ }_{2}$ EDTA, pH 7. RNA contained in the pooled aqueous phases was precipitated by addition of one volume of ethanol $\left(-20^{\circ} \mathrm{C}\right)$ after acidification with $1 / 20$ volume of $2 \mathrm{M}$ sodium acetate $\mathrm{pH} 5$. The solution was allowed to stand for $40 \mathrm{~min}$ at $-20^{\circ} \mathrm{C}$. Precipitated RNA, collected by low-speed centrifugation, was washed twice with prechilled $\left(-20^{\circ} \mathrm{C}\right) 3 \mathrm{M}$ sodium acetate at $\mathrm{pH} 5$ and $10 \mathrm{mM}$ iodoacetate. It was collected again by low-speed centrifugation, washed twice with a solution of ethanol and $0.1 \mathrm{M}$ sodium acetate, $\mathrm{pH} 5,(2: 1$, $v / v)$ and once with ethanol. The RNA was then dried under reduced pressure and redissolved in a minimal volume of distilled water. The insoluble material was eliminated by centrifugation 
and RNA concentration was estimated by using an absorption coefficient at $260 \mathrm{~nm}$ of $20 \mathrm{~cm}^{-1} \mathrm{ml} \cdot \mathrm{mg}^{-1}$. RNA was lyophilized and stored at $-80^{\circ} \mathrm{C}$.

All solutions used for extraction and purification were sterilized. Nonautoclavable equipment entering into contact with RNA was rinsed before use with $1 \%$ diethylpyrocarbonate, $1 \mathrm{mM}$ iodoacetate, then with autoclaved distilled water.

Cell-free translation in rabbit reticulocyte lysate. Translation was carried out in vitro using a nuclease-treated rabbit reticulocyte lysate prepared in our laboratory as described (I1). A standard 25 $\mu \mathrm{l}$ reaction mixture contained $12 \mu \mathrm{l}$ lysate (containing $20 \mu \mathrm{M}$ hemine), $20 \mu \mathrm{M}$ of each amino acid except labeled amino acid $\left(\left[{ }^{35} \mathrm{~S}\right]\right.$-methionine or $\left[{ }^{3} \mathrm{H}\right]$-leucine) and 2-6 $\mu \mathrm{g}$ of total high molecular weight cellular RNA. It also contained $108 \mathrm{mM}$ potassium acetate, $1 \mathrm{mM}$ magnesium acetate, $1 \mathrm{mM}$ ATP, $0.2 \mathrm{mM}$ GTP, 1 $\mathrm{mM}$ dithiothreitol, $16 \mathrm{mM}$ creatine phosphate, $80 \mu \mathrm{g} / \mathrm{ml}$ creatine phosphokinase, $0.3 \mathrm{mM}$ spermidine, $20 \mathrm{mM}$ Hepes [4-(2-hydroxyethyl)-1-piperazineethane sulfonic acid] $\mathrm{pH} 7.4$ and about 0.05 $\mathrm{mCi}\left[{ }^{35} \mathrm{~S}\right]$-methionine (specific radioactivity more than $1000 \mathrm{Ci}$ / mmole) or $0.01 \mathrm{mCi}\left[{ }^{3} \mathrm{H}\right]$-leucine (specific radioactivity of about $200 \mathrm{Ci} / \mathrm{mmole}$ ). As shown in the "Results" section, RNA, potassium acetate and magnesium acetate concentrations were chosen so as to yield an optimal incorporation of labeled amino acid into trichloroacetic acid precipitated proteins.

Incubation was carried out at $37^{\circ} \mathrm{C}$ for $1 \mathrm{~h}$. Incorporated radioactivity was determined by pipetting $1 \mu$ l of the reaction onto small pieces of Whatman $3 \mathrm{~mm}$ paper previously soaked in a 1 $\mathrm{mM}$ cold methionine or leucine solution and dried. The papers were then placed into 1 liter of a $10 \%(w / v)$ trichloroacetic acid solution which was brought to a rolling boil for $10 \mathrm{~min}$, then rinsed with water, ethanol and acetone, and air dried. The papers were incubated in scintillation bottles with $0.5 \mathrm{ml}$ Protosol at $55^{\circ} \mathrm{C}$ for $35 \mathrm{~min}$. Ten $\mathrm{ml}$ Econofluor were added and, after the bottles had been allowed to stand in ice for $30 \mathrm{~min}$, radioactivity was counted in a liquid scintillation counter. Immediately after the end of the 1-h incubation, the translation reactive mixture was diluted with $50 \mu \mathrm{l}$ of a $50 \mathrm{mM}$ Tris/ $\mathrm{HCl}$ buffer, $\mathrm{pH} 7.4$, containing $150 \mathrm{mM} \mathrm{NaCl}, 2 \%(\mathrm{v} / \mathrm{v})$ aprotinin, $10 \mathrm{mM} \epsilon$-aminocaproic acid, $10 \mathrm{mM}$ EDTA, $1 \mathrm{mM}$ diisopropylphosphofluoridate, $0.1 \mathrm{mM}$ pepstatin, $0.01 \mathrm{mM}$ leupeptin, $1 \mathrm{mM}$ methionine (or leucine), $1 \%$ (v/v) Triton X-100 and $1 \%(w / v)$ sodium deoxycholate.

Sucrose density gradient analysis of skeletal muscle RNA preparations. Analysis of RNA samples on 5-20\% linear sucrose gradients containing $50 \%(\mathrm{v} / \mathrm{v})$ dimethylsulfoxide was performed as previously described (1) after denaturation of RNA by dimethylsulfoxide and heat. All the solutions contained $10 \mathrm{mM}$ iodoacetate and $0.5 \%(\mathrm{w} / \mathrm{v})$ sodium dodecylsulphate.

Purification of the neosynthesized polypeptides by immunoaffinity chromatography. Rabbit muscle glycogen phosphorylase $b$ has been purified in our laboratory (7), and antiserum has been obtained in hens as previously described (12). Purification of specific immunoglobulins and preparation of immunoabsorbents were performed as described by Kahn et al. (9). It has been previously shown that anti-rabbit muscle glycogen phosphorylase $\mathrm{b}$ antibodies cross-react with human phosphorylase (12).

Immunoaffinity chromatography was performed on microcolumns, consisting of disposable Eppendorf tips for automatic pipets (blue tips). Antibody-Ultrogel $(5 \mu \mathrm{l})$ or nonimmune immunoglobulin-Ultrogel $(25 \mu \mathrm{l})$ was poured into tips packed with a minimum amount of siliconed glass wool. Microcolumns were inserted into each other forming a combined column with nonimmune resin at the top, then successively, a column of immunoabsorbent previously saturated with an excess of unlabeled enzyme, and a nonsaturated anti-enzyme immunoabsorbent (Fig. 1). The diluted translation mixture was centrifuged at $36,000 \times \mathrm{g}$ for $30 \mathrm{~min}$, then passed through the combined columns described above during 12 h. The different microcolumns were separated, individually washed and eluted. Washing was carried out successively with 4 $\mathrm{ml}$ of the buffer used for dilution of the translation medium, $4 \mathrm{ml}$ of $0.1 \mathrm{M}$ sodium phosphate buffer $\mathrm{pH} 7.4$, containing $1 \mathrm{M} \mathrm{KCl}$,

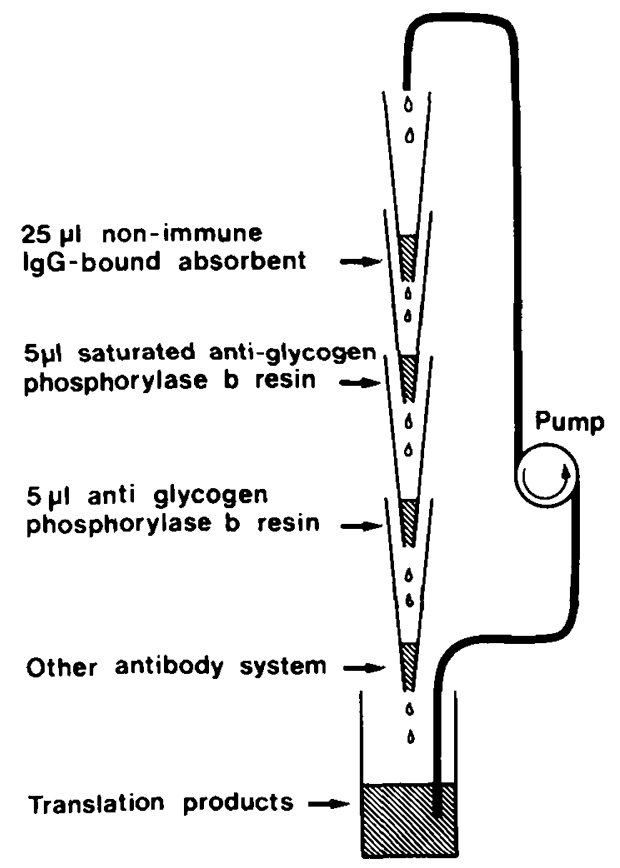

Fig. 1. Schematic procedure for the purification of the neosynthesized human muscle glycogen phosphorylase $b$ by immunoaffinity chromatography. Microcolumns were inserted into each other with the nonimmune resin at the top, then the anti-muscle glycogen phosphorylase b specific immunoabsorbent, previously saturated with an excess of unlabeled enzyme and finally the unsaturated specific immunoabsorbent. The translation mixture was allowed to pass during $12 \mathrm{~h}$ through the combined column described above. Other antibody systems could be inserted.

$2 \%(\mathrm{v} / \mathrm{v})$ aprotinin, $1 \mathrm{mM}$ diisopropylphosphofluoridate and 1 $\mathrm{mM}$ methionine; then $4 \mathrm{ml}$ of $0.1 \mathrm{M}$ sodium phosphate buffer containing $0.15 \mathrm{M} \mathrm{NaCl}$. Elution was provoked by $0.8 \mathrm{ml}$ of $0.1 \%$ $(\mathrm{w} / \mathrm{v})$ of sodium dodecyl sulphate in $10 \%(\mathrm{v} / \mathrm{v})$ acetic acid. The eluate was lyophilized, then taken up in $40 \mu \mathrm{l}$ of $0.0625 \mathrm{M}$ Tris/ $\mathrm{HCl}$ buffer pH 6.8 containing $5 \%$ (v/v) 2-mercaptoethanol, $10 \%$ $(v / v)$ glycerol and $0.001 \%(w / v)$ bromophenol blue. The final dodecyl sulphate concentration in these samples was, therefore, $2 \%$. After dissociation for $2 \mathrm{~min}$ in boiling water, they were ready for dodecyl sulphate/polyacrylamide gradient gel electrophoresis. Electrophoresis, autoradiography and fluorography. The neosynthesized polypeptides were analyzed by dodecyl sulphate/polyacrylamide gradient gel electrophoresis, according to Laemmli (10), except that the running gel was $9-24 \%(w / v)$ acrylamide. Labeled proteins used as standards of molecular weight were obtained by reductive alkylation as previously described (6). Labeled myosin, phosphorylase, bovine serum albumin, ovalbumin, carbone anhydrase, lactoglobulin $\mathrm{A}$, and cytochrome $\mathrm{c}$ were supplied by New England Nuclear. Human $M$ type phosphofructokinase, L' erythrocyte pyruvate kinase and glucose phosphate isomerase were labeled in our laboratory. After the gels had been dried, the crude translation products were detected by the autoradiography, using No-Screen films, and the immuno-purified glycogen phosphorylase b by fluorography (2), using preflashed XR-1 films. The amounts of labeled enzyme were estimated by cutting out the corresponding gel slide, then by counting the radioactivity in Econofluor, after a $24 \mathrm{~h}$ incubation at $37^{\circ} \mathrm{C}$ in 0.5 $\mathrm{ml}$ Protosol.

\section{RESULTS}

Purification of total skeletal muscle RNA. The technique of purification of high molecular weight total cellular RNA, reported in this study, allowed us to obtain, starting from $150 \mathrm{mg}$ of fresh tissue, about $12-15 \mu \mathrm{g}$ RNA. Final RNA production was a linear function of the initial amount of fresh tissue (Fig. 2). A 48-h initial 
ethanol precipitation yielded better results than a shorter ethanol precipitation $(97.6 \mu \mathrm{g}$ RNA per $\mathrm{g}$ after a $12-\mathrm{h}$ initial precipitation, $130.4 \mu \mathrm{g}$ RNA per $\mathrm{g}$, after a 48 -h precipitation). The same results were obtained using either deltoid or vastus lateralis regardless of the age of normal controls. Omitting $E$. Coli tRNA as carrier during the initial precipitation yielded much lower total RNA production, as shown in Figure 2. It is worth noting that tRNA was eliminated during the last steps of the isolation, particularly during sodium acetate washing, as confirmed by the spectrophotometric absorption of a simultaneously treated $E$. Coli tRNA preparation. Ratio $\mathbf{A}_{260} / \mathbf{A}_{280}$ constantly approximated 1.8-2. In addition, sucrose-density gradient analysis of RNA showed sharp peaks of 18-S and 28-S ribosomal RNA in the ratio of about 1 : 1.6.

Determination of optimal translation conditions. The concentrations of RNA, potassium acetate and magnesium acetate were experimentally chosen so as to yield an optimal labeled amino acid incorporation into trichloroacetic acid precipitated proteins. As shown in Figure 3, maximum radioactivity incorporation into proteins occured for RNA concentration of $160 \mu \mathrm{g} / \mathrm{ml}$. Using $\left[{ }^{3} \mathrm{H}\right]$ -leucine as labeled aminoacid, maximal stimulation was about 12 times the level of radioactivity in the blank, determined by omitting exogenous RNA (about 2000 and $25000 \mathrm{cpm}$ per $\mu \mathrm{l}$ assay, respectively). $E$. Coli tRNA, used in the first step of total muscle RNA isolation, did not direct any significant incorporation in trichloroacetic precipitated proteins. The highest radioactive incorporation was obtained for $0.8-1.2 \mathrm{mM}$ magnesium acetate and $108 \mathrm{mM}$ potassium acetate.

The level of incorporation was maximum after a $1-h$ incubation, remained unchanged until $90 \mathrm{~min}$ (Fig. 3), and then decreased slowly for protracted incubations. Incubating at $37^{\circ} \mathrm{C}$ yielded better results than incubating at $30^{\circ} \mathrm{C}$.

In vitro analysis of neosynthesized polypeptides. The scaled down technique described in this study allows the isolation of highly translatable messenger RNA, starting from small specimen of human muscle biopsies. The translation of the isolated RNA in a cell-free system produces high molecular weight protein chains, as shown by dodecyl sulphate/polyacrylamide gradient gel electrophoresis (Fig. $4 A$ ). Several high molecular weight bands, ranging from 200,000-30,000 daltons clearly appeared to comigrate with labeled myosin heavy chain (M.W. 200,000), muscle glycogen phosphorylase b (M.W. 93,000), bovin serum albumin (M.W.

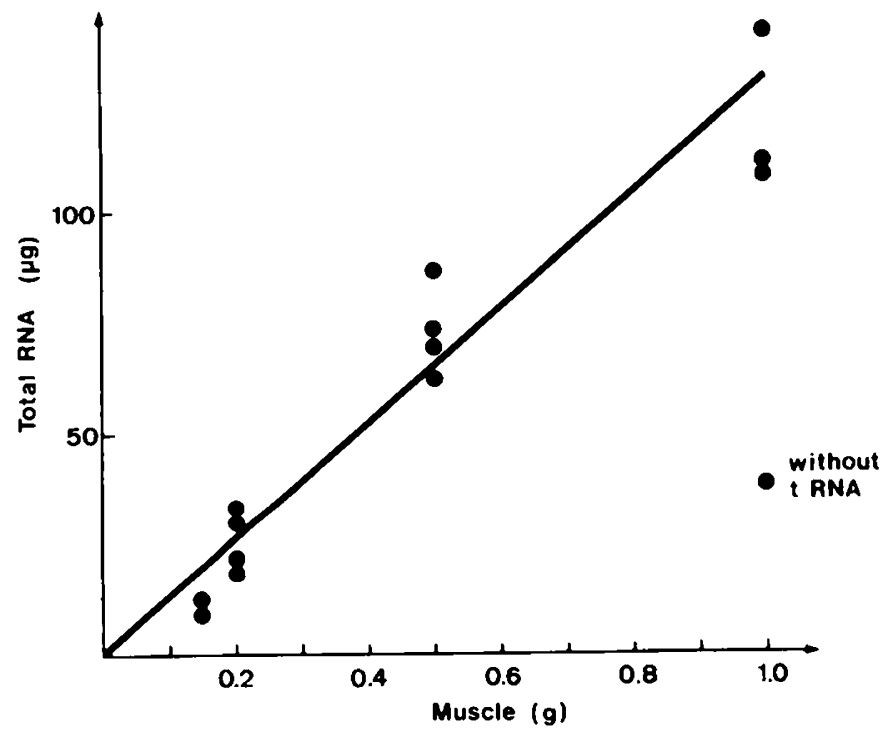

Fig. 2. Human skeletal muscle RNA recovery: the relationship between the weight of the muscle biopsy sample and the final cellular RNA recovery. The isolation of the human skeletal muscle total cellular RNA was carried out as described in the "Materials and Methods" section. RNA concentration was measured using an absorption coefficient at $260 \mathrm{~nm}$. Each point is the result of an independent experiment.

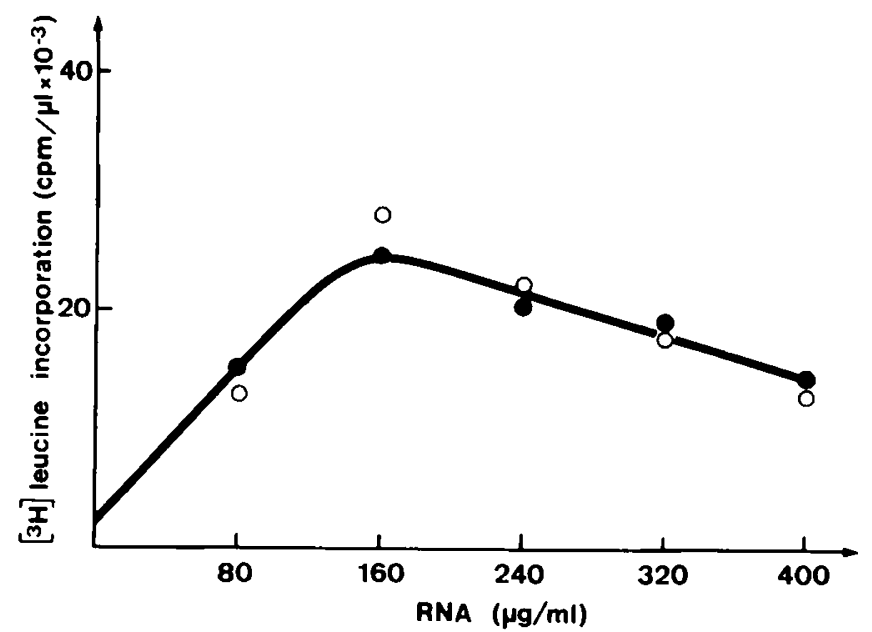

Fig. 3. Translational activity of the human skeletal muscle total cellular RNA in a cell-free reticulocyte-lysate system: the effects of time and RNA concentration on the level of the polypeptide neosynthesis. The transiation was carried out as described in the "Materials and Methods" section. The level of protein synthesis was estimated by measuring the incorporation of $\left[{ }^{3} \mathrm{H}\right]$-leucine in the trichloroacetic-acid-precipitated proteins after a $60 \mathrm{~min}$ $(O)$ and a $90 \mathrm{~min}(O)$ incubation at $37^{\circ} \mathrm{C}$.

68,000). Major bands, migrating with lactoglobulin A (M.W. 18,500 ) might correspond to several muscular proteins, including myosin light chains, troponin $\mathrm{C}$ and parvalbumin. Another band, migrating with ovalbumin should correspond to muscular actin A.

Isolation of neosynthesized glycogen phosphorylase b by immunoaffinity chromatography. Starting from a $300 \mathrm{mg}$ human muscle biopsy specimen, $40 \mu \mathrm{g}$ of total cellular RNA were isolated, then translated in a cell-free system. The translation mixture was passed on an anti-rabbit muscle glycogen phosphorylase b immunoabsorbent as described in the "Materials and Methods" section, except that translation volume was $250 \mu \mathrm{l}$ (RNA:160 $\mu \mathrm{g} / \mathrm{ml}$ ). Radioactivity incorporation $\left[{ }^{35} \mathrm{~S}\right]$-methionine approximated 28 million counts. Under these conditions, a single intense band whose molecular weight was 93,000 was detected by gradient gel electrophoresis. It migrated with the labeled human glycogen phosphorylase $b$ marker. Furthermore, this protein competed with unlabeled phosphorylase $b$ for binding to the specific immunoabsorbent since it was able to pass through the specific resin previously saturated with an excess of unlabeled enzyme before being retained on a nonsaturated specific resin. Consequently, the neosynthesized polypeptide can be identified as human muscle glycogen phosphorylase b (Fig. $4 B$ ).

\section{DISCUSSION}

Since the original study by Kahn et al. (9), it has been well established that, starting from $1 \mathrm{~g}$ of fresh tissue, it is possible to isolate highly translatable human skeletal muscle RNA by ethanol precipitation in guanidine solution. The present report provides several modifications which increase by more than 2 -fold the yield of RNA recovery. First, precipitated tRNA and ammonium acetate were added as nucleic acid carriers during the first ethanol precipitation. Second, this initial precipitation was prolonged for $48 \mathrm{~h}$. Finally, in order to avoid RNA degradation by endogeneous RNAses, the different steps of RNA isolation were carried out at $-20^{\circ} \mathrm{C}$ in the presence of lauroylsarcosine, a powerful inhibitor of RNAses. It is worth noting the extreme fragility of mRNA, especially when purified but also during the first steps of its extraction. However, if purification is undertaken as described, full-size cellular RNAs are isolated, as confirmed by the sucrose gradient analysis and by the amount of the high molecular weight neosynthesized polypeptides.

These modifications allowed us to significantly reduce the 


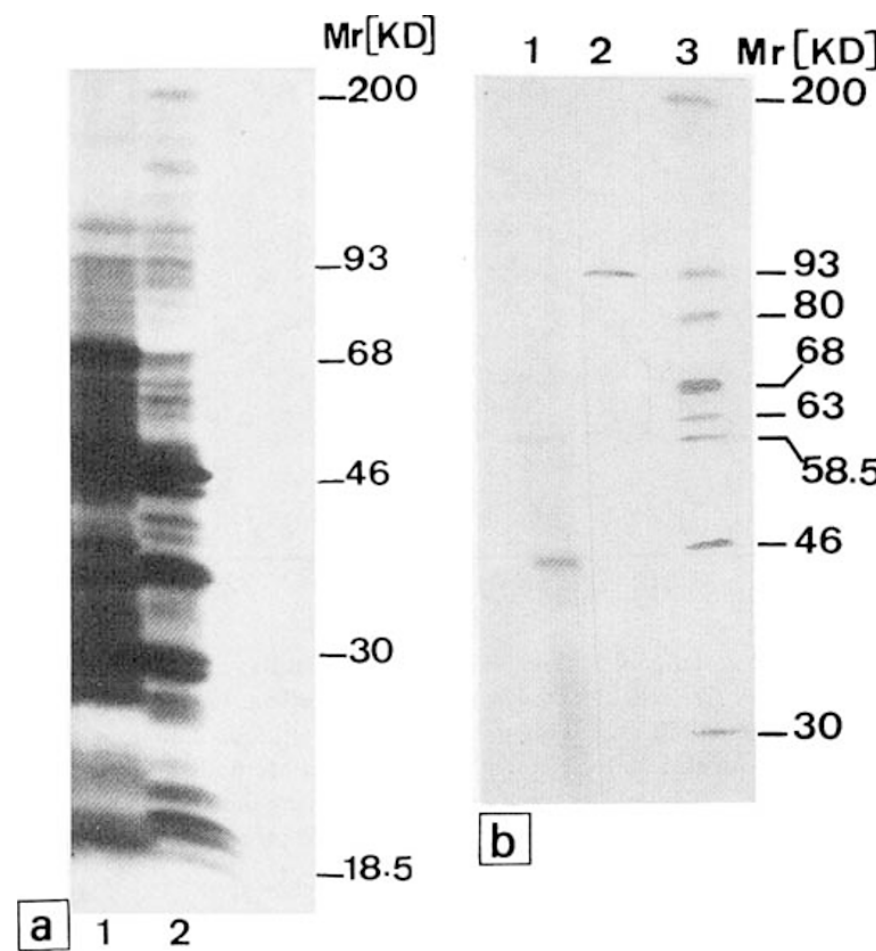

Fig. 4a. Gradient gel electrophoretic pattern of the polypeptides neosynthesized using total cellular RNA isolated from a $150 \mathrm{mg}$ child skeletal muscle biopsy sample (2) as compared to the translation product of RNA isolated from human adult liver (1). Migration at $20 \mathrm{mM} /$ plate was stopped as the dye front was at $2-5 \mathrm{~mm}$ from the bottom of the gel. Cellfree transiation was carried out as described in the "Materials and Methods" section using $\left[{ }^{3} \mathrm{H}\right]$-leucine as labeled aminoacid and $2 \mu \mathrm{l}$ of the total translation mixture were applied to the dodecyl sulfate/polyacrylamide gradient gel after dissociation by dodecyl sulfate.

Fig. 4b. Purification of the neosynthesized human glycogen phosphorylase b by immunoaffinity chromatography. Starting from a $300 \mathrm{mg}$ human muscle biopsy sample, $40 \mu \mathrm{g}$ of total RNA were purified and translated in a cell-free system using $\left[{ }^{35} \mathrm{~S}\right]$-methionine as labeled amino acid. Then, the translation mixture was passed through an anti-muscle glycogen phosphorylase $b$ immunoabsorbent as described in Figure 1 . The saturated (1) and unsaturated (2) immunoabsorbents were individually eluted and the elution product was analyzed by dodecyl sulphate/polyacrylamide gradient gel electrophoresis as described in the method section. $\left[{ }^{14} \mathrm{C}\right]$-labeled protein markers (3) were simultaneously analyzed, by order of decreasing molecular weight: myosin heavy chain, glycogen phosphorylase b, phosphofructokinase, bovin serum albumin, erythrocyte L'pyruvate kinase, glucose phosphate isomerase, ovalbumin and carbonic anhydrase.

amount of fresh tissue required for RNA purification. Starting from $150 \mathrm{mg}$ of skeletal muscle, it was possible to obtain approximately $20 \mu \mathrm{g}$ of cellular RNA containing highly translatable messengers, which directed the synthesis of high molecular weight polypeptides in a cell-free system. These polypeptides could be analyzed by gel electrophoresis of the translation product obtained with only $1 \mu \mathrm{g}$ cellular RNA. Furthermore, starting from $40 \mu \mathrm{g}$ of total RNA, (300 mg of human muscle) a cytosolic muscle enzyme, glycogen phosphorylase $b$, could be isolated from the translation mixture by an immunoaffinity chromatography procedure. Moreover, we have recently found that similar results could be obtained starting from only $200 \mathrm{mg}$ of tissue.

Our data show that neuromuscular diseases can now be studied with the tools of molecular biology, provided that the specific immunoabsorbent is available. If one considers the innocuity of a needle ( $80 \mathrm{mg}$ of tissue per puncture) or surgical biopsy taking such small amounts of muscle tissue, it is tempting to imagine the potential applications of these techniques for studying the mech- anism of several inherited metabolic diseases in childhood and for investigating pathologic changes in gene expression.

Two groups can be recognized among metabolic myopathies with known biochemical defects, such as phosphofructokinase deficiency or myophosphorylase deficiency (MacArdle's disease, glycogenosis type V): some patients have an enzymatically inactive but immunologically demonstrable protein, while others have no immunologically detectable enzyme protein (5).

In the first group, classic immunologic studies with antiserum against purified muscle enzymes can demonstrate but can barely quantify cross-reacting material in muscle biopsy specimens from these patients. The technique reported here allows one to demonstrate and quantify an immunologically detectable protein. Furthermore, it allows one to estimate the molecular weight of this protein as compared to a normal protein, but it cannot recognize an impaired post-translational modification of a high molecular weight native polypeptide.

By contrast, when no cross-reacting material is detected, one can consider a dramatic modification of the mutant protein affecting the antigenic sites, or the absence of translatable specific mRNA, or the rapid degradation of an unstable product in the intracellular conditions of the disordered muscle. In the last case, it is expected that the mutant unstable product could be nevertheless characterized in a cell-free system, especially if that system is poor in degradative enzymes or contains anti-proteases during translation reactions (9).

Moreover quantification and characterization of neosynthesized proteins from heterozygote subjects also could be of great interest, especially when their enzyme activities are much lower than the expected 50\%. Indeed, such results in heterozygotes could raise several issues for the geneticist, including double heterozygotism, unstable polymers, and reduction of the message, that could now be answered if the specific immunoabsorbent were available.

Finally, by scrutinizing the total profile of the neosynthesized polypeptides by gel electrophoresis, the present technique allows one to investigate a number of neuromuscular diseases including several neurogenic muscular diseases and muscular dystrophies.

The techniques of modern biochemical genetics are just beginning to be applied to skeletal muscle. These basic techniques are now being adaptated to serve as specific probes in studying both normal and pathologic muscle structure and functions and the interactions of nerves and muscles. One can reasonably predict that such technical advances will be of primary importance for identifying the genetic abnormalities in the metabolic myopathies as well as in the muscular dystrophies. The next step in this direction will consist of preparing cDNA probes specific for muscle mRNA in order to directly quantify these mRNAs and to look at genomic DNA. Some metabolic diseases, without crossreacting material, could indeed be caused by gene deletions which could only be detected by using such probes.

\section{REFERENCES AND NOTES}

I. Bantle, J. A., Maxwell, I. H., and Hahn, W. E.: Specificity of oligo (dT). Cellulose chromatography in the isolation of polyadenylated RNA. Anal. Biochem., 72 : 413 (1976).

2. Bonner, W. M. and Laskey, A. R.: A film detection method for tritium-labelled proteins and nucleic acids in polyacrylamide gels. Eur. J. Biochem., 46: 83 (1974).

3. Cox, R. A.: The use of guanidium chloride in the isolation of nucleic acids. Methods Enzymol., 12: 120 (1968).

4. Deeley, R. G., Gordon, J. I., Burns, A. T. H., Mullinix, K. P., Bina-Stein, M., and Goldberg, R. F.: Primary activation of the vitellogenin gene in the rooster. J. Biol. Chem., 252: 8310 (1977).

5. DiMauro S.: Metabolic myopathies: In Vinken, P. J. and Bruyn, G. N., Eds. Handbook of Clinical Neurology, Vol 42. P 175 (North Holland Publishing Co. Amsterdam 1980)

6. Dottavio-Martin, D. and Ravel, J. M.: Radiolabelling of proteins by reductive alkylation with $\left[{ }^{14} \mathrm{C}\right]$ formaldehyde and sodium cyanobromohydride. Anal. Biochem., 87: 562 (1978).

7. Fischer, E. H. and Krebs, E. G.: Muscle phosphorylase b. Methods Enzymol., 5: 369 (1962).

8. Harding, J. D., MacDonald, R. J., Przybyla, A. E., Chirgwin, J. M., Pictet, R. L., 
and Rutter W. J.: Changes in the frequency of specific transcripts during development of the pancreas. J. Biol. Chem., 252: 7391 (1977).

9. Kahn, A., Cottreau, D., Daegelen, D., and Dreyfus, J. C.: Cell-free translation of messenger RNAs from adult and fetal human muscle. Eur. J. Biochem., 116 : 7 (1981).

10. Laemmli, U. K.: Cleavage of structural proteins during the assembly of the head of bacteriophage T4. Nature, 227: 680 (1970).

11. Pelham, H. R. B. and Jackson, R. J.: An efficient mRNA-dependent translation system from reticulocyte lysates. Eur. J. Biochem., 67: 247 (1976)
12. Proux, D. and Dreyfus, J. C.: Phosphorylase isoenzymes in tissues: prevalence of the liver type in man. Clin. Chim. Acta., 48: 167 (1973).

13. The authors are thankful to Dr. Georges Schapira, Dr. Jean Frézal and Dr. Lenny Groopman for their helpful discussion.

14. Requests for reprints should be addressed to: Dr. Axel Kahn, Institut de Pathologie Moleculaire, CHU Cochin, Rue du Fbg St. Jacques, 75014 Paris Cedex 14. France.

15. Received for publication June 17, 1981

16. Accepted for publication September 29. 1981

Copyright $\odot 1982$ International Pediatric Research Foundation, Inc.

0031-3998/82/1605-0335\$02.00/0

Printed in U.S.A.

\title{
ANNOUNCEMENT
}

\section{XIVTH MEETING OF THE INTERNATIONAL SOCIETY FOR PEDIATRIC ONCOLOGY (SIOP)}

BERN, SWITZERLAND, SEPTEMBER 21-25, 1982

\author{
Main Theme: NEW MODES OF THERAPY AND SUPPORTIVE CARE \\ -Immune Modulation \\ -Monoclonal Antibodies: Clinical Applications \\ -Bone Marrow Transplantation \\ -Infection and Nutrition \\ -New Modes in Surgery \\ -New Modes in Radiooncology \\ Reports on Current Trials \\ Pathologists Meeting \\ Language: \\ English \\ Place: \\ Department of Pediatrics, Inselspital, 3010 Bern, Switzerland \\ Information: \\ Hans P. Wagner, M.D. \\ c/o SPOG \\ Institute for Clinical and Experimental Cancer Research \\ Tiefenauspital \\ 3004 Bern, Switzerland
}

